\title{
EVALUATION OF THE INFLUENCE OF THE VALUE OF THE DYNAMIC RANGE OF THE RADIO RECEIVER ON THE NOISE IMMUNITY OF RECEIVING SIGNALS WITH QUADRATURE AMPLITUDE MODULATION
}

Vitaly G. Dovbnya,

Southwest State University, Kursk, Russia, vit_georg@mail.ru

Dmitry S. Koptev,

Southwest State University, Kursk, Russia, d.s.koptev@mail.ru

Ivan G. Babanin,

Southwest State University, Kursk, Russia, babanin_ivan@bk.ru

Alexander A. Knyazev,

Southwest State University, Kursk, Russia
Manuscript received 24 February 202I;

Accepted 30 March 202I

Keywords: radio receiver, dynamic range, noise immunity, equivalent energy losses, digital information transmission lines

\begin{abstract}
The improvement of digital communication lines of radio information transmission systems in the direction of increasing the complexity of the signal-code structures used, increasing the speed of information exchange, the use of modern channel compaction technologies, on the one hand, and the high complexity of the surrounding electromagnetic environment, on the other hand, objectively determines the need to improve the radio receiving systems of digital communication lines in the direction of increasing their noise immunity. In this regard, in order to justify the technical requirements for noise immunity to radio receiving systems of the designed transmission lines, it is advisable to take into account the basic indicators of the quality of functioning of the radio receiving device, in order to obtain analytical expressions and graphical dependencies for evaluating the noise immunity of receiving signals with more complex combined types of modulation (QAM-64 and higher), used and planned for use. Of the large number of indicators that characterize the dynamic range, the most informative and sufficiently characterize the quality of the linear path are: the dynamic range for reducing the transmission coefficient (compression) by I $\mathrm{dB}$ and the dynamic range for third-order intermodulation distortion. The effect of interference received on the side channels (which include combination and mirror), as well as on neighboring channels, limits the lower limit of the dynamic range of the receiving device and, as a result, reduces the resulting signal-to-noise ratio at the output. The degree of suppression of the combination channels is determined, first of all, by the frequency plan and the linearity of the amplitude characteristic of the mixer of the first frequency converter, the mirror channel - the quality of filtering the mirror frequencies in the input preselector, the neighboring channel - the selectivity of the filters of the main selection. In this article, an analytical model and the resulting graphical dependencies are developed to assess the degree of influence of compression distortions on the noise immunity of receiving multi-position quadrature-amplitude modulated signals, and the requirements for the value of the dynamic range of radio receiving systems are theoretically justified.
\end{abstract}

Information about authors:

Vitaly G. Dovbnya, Doctor of Engineering Sciences, Associate Professor, Professor at the Department of Space Instrumentation and Communication Systems, Southwest State University, Kursk, Russia

Dmitry S. Koptev, Lecturer at the Department of Space Instrumentation and Communication Systems, Southwest State University, Kursk, Russia Ivan G. Babanin, Candidate of Engineering Sciences, Associate Professor of the Department of Space Instrumentation and Communication Systems, Southwest State University, Kursk, Russia

Alexander A. Knyazev, Student of the Department of Space Instrumentation and Communication Systems, Southwest State University, Kursk

Для цитирования:

Довбня В.Г., Коптев Д.С., Бабанин И.Г., Князев А.А. Оценка влияния значения динамического диапазона радиоприёмного устройства на помехоустойчивость приема сигналов с квадратурной амплитудной модуляцией // Т-Соmm: Телекоммуникации и транспорт. $202 \mathrm{I}$. Том I5. №6. С. 65-69.

For citation:

Dovbnya V.G., Koptev D.S., Babanin I.G., Knyazev A.A. (2021)Evaluation of the influence of the value of the dynamic range of the radio receiver on the noise immunity of receiving signals with quadrature amplitude modulation. T-Comm, vol. 15, no.6, Pp. 65-69. (in Russian) 


\section{Introduction}

One of the main indicators of the quality of the receiving device, which determines its ability to transform the signal without introducing additional nonlinear (compression) distortions, is the dynamic range. Signals with quadrature amplitude modulation are the most critical to this type of distortion, since their quadrature components are signals with multi-level amplitude manipulation. One of the dynamic range indicators that sufficiently characterizes the quality of the linear path is the value of the dynamic range to reduce the transmission coefficient by $1 \mathrm{~dB}$.

The paper [1] evaluates the degree of influence of compression distortions on the noise immunity of digital signal reception. However, the expressions obtained in this paper for calculating the probability of bit error are limited to considering signals with quadrature amplitude modulation with a positionality of no more than 64. The disadvantage of the analytical model proposed in [1] is that not only the amplitudes of the quadrature components of the signal are subjected to compression distortions, but also the decision thresholds, which is not the case in practice. In addition, a significant increase in the amount of computational costs with an increase in the positionality of quadrature-amplitude modulated signals significantly limits the possibilities of using the analytical model used.

\section{Materials and research methods}

The value of the dynamic range of the radio receiver by reducing the transmission coefficient by $1 \mathrm{~dB} \mathrm{Db}_{-1 \mathrm{~dB}}$ can be estimated from the amplitude characteristic of its linear path, the typical form of which is shown in Figure 1.

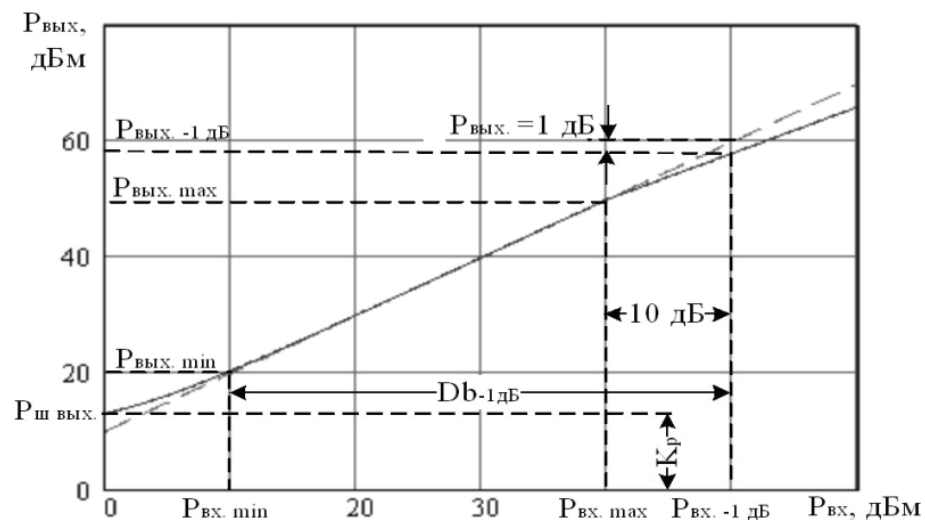

Figure 1. Typical form of the amplitude characteristic of the linear path of the receiving device

The dashed line indicates an idealized characteristic that has a slope of $\pi / 4$ radians and an offset along the ordinate axis by an amount equal to the power gain of the linear path $K_{p}$; solid - a real characteristic that has a deviation from the linear dependence in the range of small and large values of the power of the amplified signal.

The deviation of the amplitude characteristic from the linear one in the region of large power values $\left(P_{b x} \geq P_{b x \text {.max }}\right)$ leads to the appearance of compression distortions of signal realizations, the peak power of which falls into the specified region. As a rule, at peak power values below the upper limit of the dynamic range by $10 \mathrm{~dB}$, the level of compression distortion is reduced so much that they can be ignored $[2,3,4]$.

To evaluate the influence of the dynamic range on the noise immunity of radio receiving systems, we find the dependence of the bit error probability on the degree of non-linearity of the amplitude characteristic, for which we use the method described in work 5. In this case, the degree of non-linearity of the amplitude characteristic will be evaluated by the relative change in the transmission coefficient of the linear path.

Without violating the generality of reasoning, we set in the model of radio receiving facilities equal to zero $\psi_{R}(t), \psi_{V}(t), \tau_{R}(t), \zeta_{x}(t), \zeta_{y}(t) \cdot$

Then, taking into account the assumptions made, the envelopes of the quadrature components of the distorted signal $U_{x}(t), U_{y}(t)$ and the decision rule can be written, respectively, in the following form:

$$
\begin{aligned}
& U_{x}(t)=\mu_{x r} d G_{\Sigma}(t) m_{r}+N_{R x}(t) \\
& U_{y}(t)=\mu_{y r} d G_{\Sigma}(t) n_{r}+N_{R y}(t) \cdot \\
& m_{r}\left(\mu_{x r} m_{r}-\frac{\mu_{0} m_{r}}{2}\right)+n_{r}\left(\mu_{y r} n_{r}-\frac{\mu_{0} n_{r}}{2}\right)+ \\
& +\frac{m_{r} N_{R x 0}+n_{r} N_{R y 0}}{d G_{\Sigma 0}}>m_{p}\left(\mu_{x r} m_{r}-\frac{\mu_{0} m_{p}}{2}\right)+ \\
& +n_{p}\left(\mu_{y r} n_{r}-\frac{\mu_{0} n_{p}}{2}\right)+\frac{m_{p} N_{R x 0}+n_{p} N_{R y 0}}{d G_{\Sigma 0}}, r \neq p
\end{aligned}
$$

where $G_{\Sigma 0}=G_{\Sigma}\left(\tau_{0}\right)$ - the value of the envelope of the impulse response of the channel at the time of decision-making;

$N_{R x 0}=N_{R x}\left(\tau_{0}\right), N_{R y 0}=N_{R y}\left(\tau_{0}\right)$ - the values of the envelopes of the quadrature components of the noise at the time of decision-making;

$\mu_{0}-$ nominal transmission coefficient of the linear path;

$\mu_{x r}, \mu_{y r}$ - the transmission coefficients of the linear path, respectively, for the common-mode and quadrature components of the $r$-th signal realization.

The decision in the radio receiving system is made for each of the envelope quadrature components of the signal implementation separately in accordance with the following inequalities:

$$
\left\{\begin{array}{c}
\left(m_{p}-m_{r}\right)\left[0,5 \mu_{0}\left(m_{p}+m_{r}\right)-\mu_{x r} m_{r}\right]>\left(m_{p}-m_{r}\right) N_{R x 0} / d G_{\Sigma 0}, \\
\left(n_{p}-n_{r}\right)\left[0,5 \mu_{0}\left(n_{p}+n_{r}\right)-\mu_{y r} n_{r}\right]>\left(n_{p}-n_{r}\right) N_{R y 0} / d G_{\Sigma 0}, r \neq p
\end{array}\right.
$$

or

$\left\{\begin{array}{c}\operatorname{sgn}\left(m_{p}-m_{r}\right)\left[0,5\left(m_{p}-m_{r}\right)+k_{x r} m_{r}\right]>N_{R x 0} / \mu_{0} d G_{\Sigma 0}, \\ \operatorname{sgn}\left(n_{p}-n_{r}\right)\left[0,5\left(n_{p}-n_{r}\right)+k_{y r} n_{r}\right]>N_{R y 0} / \mu_{0} d G_{\Sigma 0}, r \neq p,\end{array}\right.$

where $\operatorname{sgn}(x)=\left\{\begin{array}{l}1, x>0,- \text { sign function; } \\ -1, x<0\end{array}\right.$ 
$k_{x r}=\frac{\mu_{0}-\mu_{x r}}{\mu_{0}}, k_{y r}=\frac{\mu_{0}-\mu_{y r}}{\mu_{0}}-$ relativ changes in the transmission coefficients of the linear path for the common-mode and quadrature components of the $r$-th signal realization.

Assuming that the quadrature channels are identical, we obtain an expression for the conditional probability of error in receiving a symbol in the form

$$
P_{s}\left(k_{r}\right) \approx 2 P\left(\operatorname{sgn}(p-r)\left[0,5(p-r)+k_{r} r\right]<\xi\right), r \neq p,
$$

where

$$
r, p=\{-(L-1),-(L-3), \ldots,(L-1)\}
$$

$\xi=N_{R \times 0} / \mu_{0} d G_{\Sigma 0}$ - centered normally distributed random variable with dispersion $\sigma_{\xi}^{2}=N_{0} / \mu_{0}^{2} d^{2} G_{\Sigma 0}^{2} T$.

Therefore, the conditional probability matrix of size L (L-1) in the considered case will be equal to

$\left\|P_{p, r}\left(k_{r}\right)\right\|=\left\|\begin{array}{cccc}P_{-(L-1),-(L-3)}\left(k_{r}\right) P_{-(L-1),-(L-5)}\left(k_{r}\right) & \ldots & P_{-(L-1), L-1}\left(k_{r}\right) \\ P_{-(L-3),-(L-1)}\left(k_{r}\right) P_{-(L-3),-(L-5)}\left(k_{r}\right) & \ldots & P_{-(L-3), L-1)}\left(k_{r}\right) \\ \ldots & \ldots & \ldots & \ldots \\ P_{L-1,-(L-1)}\left(k_{r}\right) & P_{L-1,-(L-3)}\left(k_{r}\right) & \ldots & P_{L-1, L-3}\left(k_{r}\right)\end{array}\right\|$

$r \neq p$,

where

$P_{p, r}\left(k_{r}\right)=P\left(p / r, k_{r}\right)=Q\left\{\sqrt{\frac{3}{M-1}} h \operatorname{sgn}(p-r)\left[0,5(p-r)+k_{r} r\right]\right\}$

- the probability that when transmitting the implementation of a signal with the parameter $r$, will be accepted the implementation of a signal with the parameter $p$.

Omitting the intermediate transformations and assuming the elements of the matrix (6), for which $|0,5(p-r)| \neq 1$ equal to zero, we obtain an expression for the conditional probability of error per bit:

$$
P_{b}\left(h, k_{l-1}\right)=\frac{2}{L \log _{2} L} \sum_{l} Q\left\{\sqrt{\frac{3}{M-1}} h\left[1+k_{l-1}(l-1)\right]\right\}
$$

or

$$
P_{b}\left(h, k_{l-1}\right)=\frac{1}{L \log _{2} L} \sum_{l} \operatorname{erfc}\left\{\sqrt{\frac{1,5}{M-1}} h\left[1+k_{l-1}(l-1)\right]\right\},
$$

where $k_{l-1}$ - linear path transmission coefficient for signal realizations with the level of amplitudes of quadrature components $(l-1) ; l=\{-(L-2),-(L-4), \ldots,(L-2)\}$.

\section{Results and discussion}

Figure 2 shows the dependence of the equivalent energy losses of receiving signals QAM-16, QAM-64, QAM-256, QAM1024 respectively, on the values of the dynamic range for the probabilities of bit errors $10^{-7}, 10^{-5}, 10^{-3}$, calculated by the iterative method in MathCad 11 using the expression (7). In the calculation, it was assumed that the relative deviation of the transmission coefficient of the linear path in the range of values $P_{g x .} \geq P_{g x \text { max }}$ is minus $1 \mathrm{~dB}$ per decade of change in the input signal power.

From the analysis of the obtained graphs, it follows that to ensure high-quality reception of digital signals, the minimum value of the dynamic range in the linear path of the radio receiver device should be at least 35, 42, 49 and $55 \mathrm{~dB}$, respectively, for the signals QAM-16, QAM-64, QAM-256, QAM-1024. When justifying the requirements for radio receiving devices, the above values should be adjusted upwards to the level of the predicted resulting equivalent energy losses of reception.

For engineering calculations, the minimum required value of the dynamic range for compression by $1 \mathrm{~dB}$ can be estimated using an empirical dependence [7]

$$
D b_{-1 \partial \zeta}=h_{b}^{2}\left(P_{b 0}\right)+20 \lg (L-1)+\Delta h_{\Sigma}^{2}+10,
$$

where $h_{b}^{2}\left(P_{b 0}\right)$ - the ratio of the bit energy $E_{b}$ to the one-way spectral noise power density $N_{0}$, required to obtain the required bit error probability in the limit, $\mathrm{dB}$;

$\Delta h_{\Sigma}^{2}$ - predicted resulting equivalent energy losses when receiving signals, taking into account interference on the combination channels of reception, $\mathrm{dB}$.

The correction factor in expression (9), equal to ten, characterizes the difference of $10 \mathrm{~dB}$ between $P_{\text {вх.max }}$ и $P_{\text {вх.-1 дь }}$.

Given that the signal-to-noise ratio per bit and per symbol of information $h_{b}^{2}$ and $h^{2}$ are related by the expression $[8,9]$

$$
h_{b}^{2}=\frac{3}{M-1} h^{2}
$$

let's rewrite the expression (9) in the following form:

$$
D b_{-1 \partial 5}=h^{2}\left(P_{b 0}\right)+10 \lg \frac{3(L-1)^{2}}{M-1}+\Delta h_{\Sigma}^{2}+10 .
$$

For multi-position signals, we have:

$$
\frac{(L-1)^{2}}{M-1} \approx 1
$$

Then the minimum required value of the dynamic range is

$$
D b_{-1 \partial \zeta}=h^{2}\left(P_{b 0}\right)+\Delta h_{\Sigma}^{2}+14,8
$$



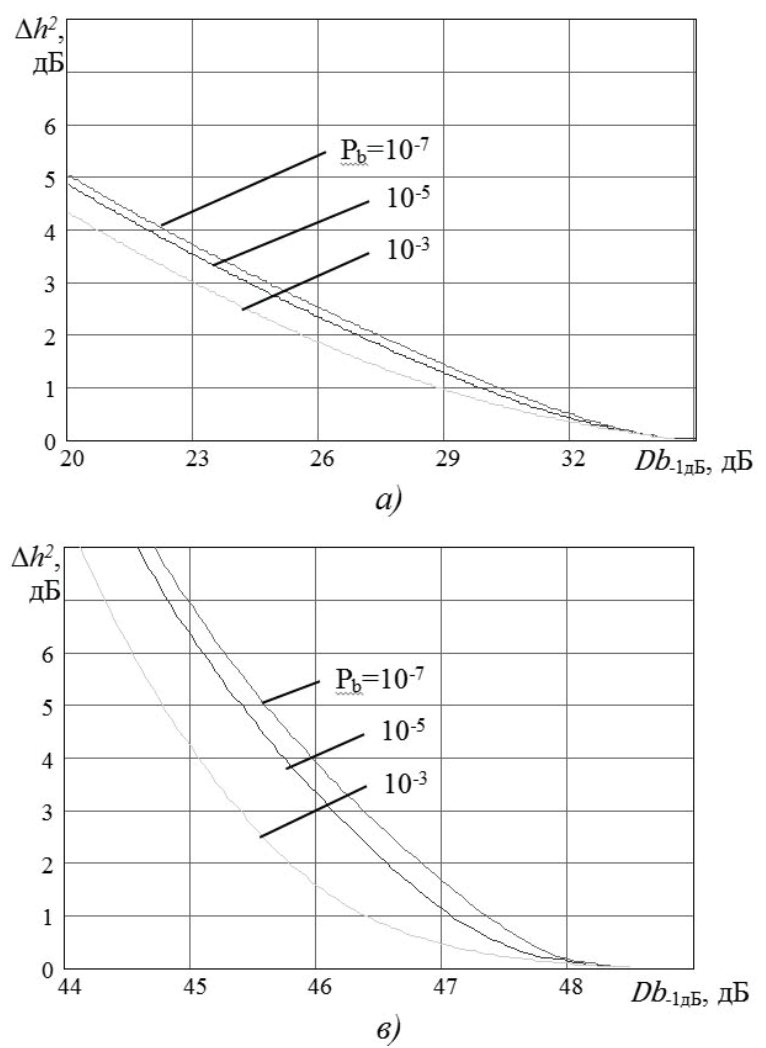
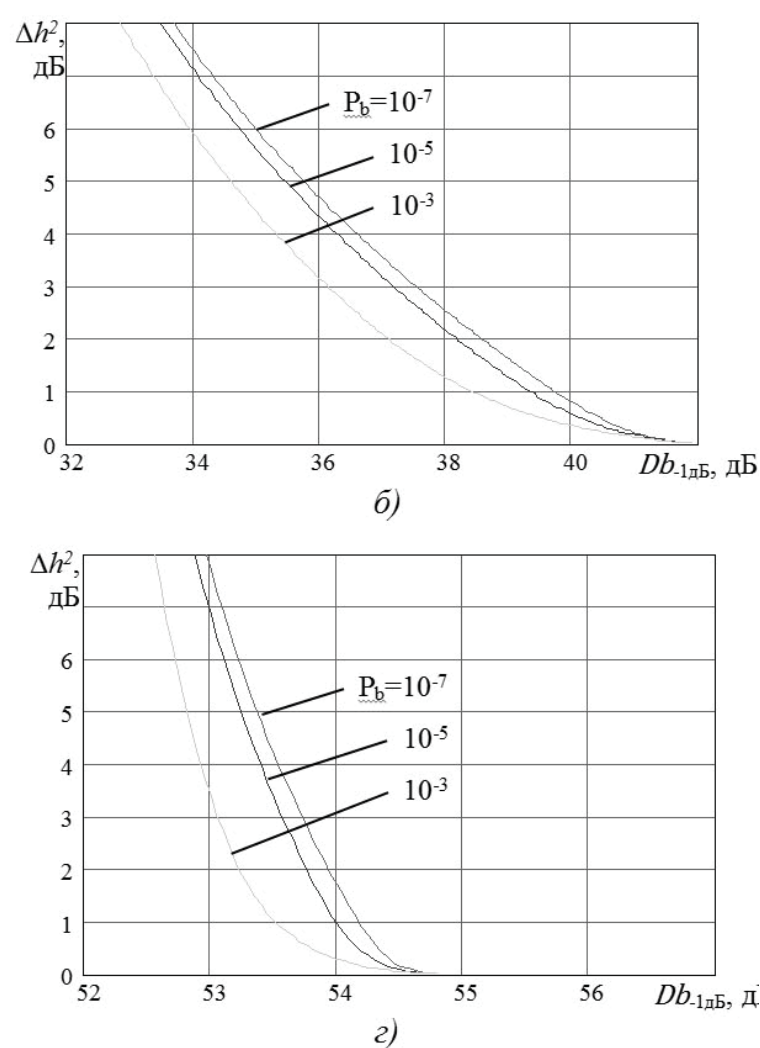

Figure 2. Dependence of the equivalent energy loss on the dynamic range value for the signal: a - QAM-16; 6 - QAM-64; в - QAM-256; г - QAM-1024

If you set the probability of a bit error of $10^{-7}$ (Figure 2) and the value of the expected equivalent energy losses at the level of 4 to $6 \mathrm{~dB}$ (which corresponds to the technical requirements for signals of the QAM-256 and QAM-1024 types), then the minimum value of the dynamic range of the linear path of the receiving device should be from 52 to 54 and from 58 to $60 \mathrm{~dB}$, respectively for signals of QAM-256 and QAM-1024.

\section{Conclusion}

The developed analytical model and the obtained graphical dependencies allow us to assess the degree of influence of compression distortions on the noise immunity of receiving multiposition signals, as well as to theoretically justify the requirements for the value of the dynamic range of radio receiving systems. For high-quality (with an acceptable level of equivalent energy losses from 0,2 to $0,3 \mathrm{~dB}$ ) reception of signals with complex types of modulation (up to QAM-1024) in the receiving device, it is necessary to provide a dynamic range for compression of the transmission coefficient by $1 \mathrm{~dB}$ of at least $60 \mathrm{~dB}$.

\section{References}

1. V.E. M tirosov (2008). Influence of nonlinear (compression) distortions on the noise immunity of receiving QAM signals. Radio engineering. No. 9. P. 4-11.
2. M. S. Nemi vsky (1980). Digital transmission of information in radio communications. Moscow: Communication. 256 p.

3. S.M. Kli , A.S. Krivenko, G.N. Nosikov and others (1976). 5Design of radio receivers: textbook. manual for universities. Moscow: Sov. radio. $486 \mathrm{p}$.

4. V.I. Korzh , L.M. Fink, K.N. Shchelkunov (1981). Calculation of noise immunity of systems of transmission of discrete messages: a reference book; ed. L. M. Fink. Moscow: Radio and communication, 1981. $232 \mathrm{p}$.

5. V. N. Ban v, L.G. Barulin, M.I. Zhodzishsky, I. V. Malyshev, V. V. Petrusinsky (1984). Radio receivers; ed. L. G. Barulina. Moscow: Radio and communication. $272 \mathrm{p}$.

6. V.V. ednarsky, V.G. Dovbnya, O.V. Yakovlev (2004). Immunity of receiving digital signals with combined types of keying. Telecommunications. No. 4. P. 2.

7. V.G. Dov ya, V.E. Aziatsev, S.N. Mikhailov (2017). Noise immunity of radio receiving systems of digital communication lines: monograph. Southwest. state un-t. Kursk. 175 p.

8. V Lindsay (1978). Synchronization systems in communication and control. Moscow: Sov. radio. 466 p.

9. A.N. Bormin y, P.G. Kaplunov (1994). Normalization of heterodyne characteristics for digital radio communication systems with multi-position quadrature amplitude modulation. Electrosvyaz. No. 4. P. 19-20.

10. V.G. D ya (2010). Immunity of receiving digital signals with combined types of keying. Telecommunications. No. 7. P. 41-44.

11. V.G. Do ya, A.E. Sevryukov (2016). Influence of nonlinear distortions on noise immunity of receiving signals with quadrature amplitude modulation. Design and technology of electronic means. No. 1. P. 14-19. 


\title{
ОЦЕНКА ВЛИЯНИЯ ЗНАЧЕНИЯ ДИНАМИЧЕСКОГО ДИАПАЗОНА РАДИОПРИЁМНОГО УСТРОЙСТВА НА ПОМЕХОУСТОЙЧИВОСТЬ ПРИЕМА СИГНАЛОВ С КВАДРАТУРНОЙ АМПЛИтУДНОЙ МОдУЛЯЦИЕй
}

\begin{abstract}
Довбня Виталий Георгиевич, Юго-Западный государственный университет, г. Курск, Россия, vit_georg@mail.ru Коптев Дмитрий Сергеевич, Юго-Западный государственный университет, г. Курск, Россия, d.s.koptev@mail.ru Бабанин Иван Геннадьевич, Юго-Западный государственный университет, г. Курск, Россия, babanin_ivan@bk.ru Князев Александр Александрович, Юго-Западный государственный университет, г. Курск, Россия
\end{abstract}

\section{Аннотация}

Совершенствование цифровых линий связи радиосистем передачи информации в направлении усложнения используемых сигнально-кодовых конструкций, возрастания скоростей информационного обмена, использования современных технологий уплотнения каналов, с одной стороны, и высокая сложность окружающей электромагнитной обстановки, с другой стороны, объективно обусловливает необходимость совершенствования радиоприемных систем цифровых линий связи в направлении повышения их помехоустойчивости. В связи с этим для обоснования технических требований по помехоустойчивости к радиоприемным системам проектируемых линий передачи целесообразно учитывать базовые показатели качества функционирования радиоприемного устройства, для того, чтобы получить аналитические выражения и графические зависимости для оценки помехоустойчивости приема сигналов с более сложными комбинированными видами модуляции (КАМ-64 и выше), применяемых и планируемых к применению. Из большого числа показателей, характеризующих динамический диапазон, наиболее информативными и в достаточной степени характеризующими качество линейного тракта являются: динамический диапазон по уменьшению коэффициента передачи (компрессии) на І дБ и динамический диапазон по интермодуляционным искажениям третьего порядка. Воздействие помех, принимаемых по побочным (к которым относятся комбинационные и зеркальный), а также по соседним каналам, ограничивает нижнюю границу динамического диапазона приемного устройства и, как следствие, уменьшает результирующее отношение сигнал/шум на выходе. Степень подавления комбинационных каналов определяется, прежде всего, частотным планом и линейностью амплитудной характеристики смесителя первого преобразователя частоты, зеркального канала - качеством фильтрации зеркальных частот во входном преселекторе, соседнего канала избирательностью фильтров основной селекции. В данной статье разработана аналитическая модель и получены графические зависимости, позволяющие оценить степень влияния компрессионных искажений на помехоустойчивость приема многопозиционных квадратурно-амплитудно модулированных сигналов, а также теоретически обоснованы требования к значению динамического диапазона радиоприемных систем.

Ключевые слова: радиоприемное устройство, динамический диапазон, помехоустойчивость, эквивалентные энергетические потери, цифровые линии передачи информации.

\section{Литература}

І. Мартиросов В.Е. Влияние нелинейных (компрессионных) искажений на помехоустойчивость приема сигналов QАМ // Радиотехника. 2008. №9. C. 4-II.

2. Немировский М.С. Цифровая передача информации в радиосвязи. М.: Связь, 1980. 256 с.

3. Клич С.М., Кривенко А.С., Носикова Г.Н. и др. Проектирование радиоприемных устройств: учеб. пособие для вузов. М.: Сов. радио, І976. 486 с.

4. Коржик В.И., Финк Л.М. , Щелкунов К.Н. Расчет помехоустойчивости систем передачи дискретных сообщений: справочник; под ред. Л. М. Финка.

М.: Радио и связь, 1981. 232 с.

5. Банков В.Н., Барулин Л.Г., Жодзишский М.И., Малышев И.В., Петрусинский В.В. Радиоприемные устройства; под ред. Л. Г. Барулина. М.: Радио и связь, 1984. 272 с.

6. Беднарский В.В., Довбня В.Г., Яковлев О.В. Помехоустойчивость приёма цифровых сигналов с комбинированными видами манипуляции // Телекоммуникации. 2004. №4. С. 2.

7. Довбня В.Г., Азиатиев В.Е., Михайлов С.Н. Помехоустойчивость радиоприёмных систем цифровых линий связи: монография. Юго-Зап. гос. ун-т. Курск, 2017. 175 с.

8. Линдсей В. Системы синхронизации в связи и управлении: [пер. с англ.]. М.: Сов. радио, 1978.466 с.

9. Борминский А.Н., Каплунов П.Г. Нормирование характеристик гетеродинов для цифровых систем радиосвязи с многопозиционной квадратурной амплитудной модуляцией // Электросвязь. 1994. №4. С. 19-20.

10. Довбня В.Г. Помехоустойчивость приёма цифровых сигналов с комбинированными видами манипуляции // Телекоммуникации. 20 І0. №7. С. $4 I-44$.

II. Довбня В.Г., Севрюков А.Е. Влияние нелинейных искажений на помехоустойчивость приема сигналов с квадратурной амплитудной модуляцией // Проектирование и технология электронных средств. 2016. №І. С. I4-I9.

Информация об авторах:

Довбня Виталий Георгиевич, д.т.н., доцент, профессор кафедры космического приборостроения и систем связи, Юго-Западный государственный университет, г. Курск, Россия

Коптев Дмитрий Сергеевич, преподаватель кафедры космического приборостроения и систем связи, Юго-Западный государственный университет, г. Курск, Россия

Бабанин Иван Геннадьевич, к.т.н., доиент кафедры космического приборостроения и систем связи, Юго-Западный государственный университет, г. Курск, Россия

Князев Александр Александрович, студент кафедры космического приборостроения и систем связи, Юго-Западный государственный университет, г. Курск, Россия 